\title{
Recycle Afalan Kemasan Aluminium Foil Sebagai Koagulan Pada IPAL
}

\section{Recycle Of Aluminium Foil Waste From Packaging As Coagulant \\ On Wastewater Treatment}

\author{
Nurul Mahmida Ariani \\ Kementerian Perindustrian \\ Balai Riset dan Standardisasi Industri Surabaya \\ Surabaya, Indonesia \\ baristandsurabaya@yahoo.com
}

\author{
Liayati Mahmudah \\ Kementerian Perindustrian \\ Balai Riset dan Standardisasi Industri Surabaya \\ Surabaya, Indonesia \\ baristandsurabaya@yahoo.com
}

\begin{abstract}
Abstrak - Meningkatnya industri makanan kemasan, sebanding dengan jumlah limbah padat yang dihasilkan. Limbah padat afalan kemasan aluminium foil dari industri makanan ini direcyle untuk menjadi alumunium sulfat yang dapat dimanfaatkan untuk bahan penolong dalam proses pengolahan air limbah. Tawas kalium aluminium sulfat dihasilkan dengan mereaksikan logam aluminium (Al) dalam larutan basa kuat yang akan larut membentuk aluminat. Larutan aluminat dinetralkan dengan asam sulfat. Variabel yang digunakan antara lain limbah alumunium foil jenis coated (warna) dan uncoated (polos), variabel basa yang digunakan yaitu larutan $\mathrm{NaOH}$ dan $\mathrm{KOH}$. Dari beberapa percobaan diperoleh bahwa kondisi optimum terjadi pada jenis aluminium foil polos/uncoated yang direaksikan dengan KOH $5 \%$, kemudian dinetralkan dengan $\mathrm{H}_{2} \mathrm{SO}_{4} 1 \mathrm{M}$ dan dihasilkan tawas cair sebesar 3,1\%. Tawas yang dihasilkan memiliki performa yang sama baiknya dengan tawas komersil hanya membutuhkan jumlah yang lebih banyak karena kadar yang dihasilkan masih jauh dibawah kadar tawas komersil.
\end{abstract}

Kata Kunci - limbah afalan, alumunium foil, coated, uncoated, alumunium sulfat

\begin{abstract}
The increase of packaged food and baverages industries, is followed with the increase of the resulting solid waste. Alumunium foil Waste from packaging on Food and beverages can be processed into Aluminium Sulfide, as supporting agent on Wastewater treatment. Aluminium sulfide is produced by reacting aluminium $(A l)$ with alkaline solution, that dissolve it to be aluminate and then neutralized by sulfuric acid. The variables of this research are the type of aluminium foil (coated and uncoated) and the types of alkaline solution ( $\mathrm{NaOH}$ and $\mathrm{KOH}$ ). The best process are Alumunium foil reacted with $\mathrm{KOH} 5 \%$, then neutralized by $\mathrm{H}_{2} \mathrm{SO}_{4} 1 \mathrm{M}$ which produces $3,1 \%$ of aluminium sulfate. Aluminium sulfate that was produced is as a good as the commercial one, but just requiring higher amount since the composition produced is still lower.
\end{abstract}

Keywords - solid waste, alumunium foil, coated, uncoated, alumunium sulfate

\section{PENDAHULUAN}

Industri makanan dan minuman dalam kemasan berkembang sangat pesat, karena kecenderungan konsumen untuk memilih produk siap saji yang lebih praktis. Umumnya kemasan yang digunakan aluminium foil, film plastik, selopan, film plastik berlapis logam aluminium (metalized film) dan kertas.

Foil adalah bahan tipis dari logam yang digulung dengan ketebalan kurang dari 0,15 mm dan memiliki lebar 1,52 meter hingga 4,06 meter. Umumnya foil tidak murni berbasis logam. Karakteristik aluminum foil kuat, ringan, tahan panas, dan hampir kedap udara, tidak mengandung magnet. Kekedapan terhadap oksigen membuat aluminum foil merupakan kemasan ideal

Dari Industri makanan dan minuman yang ada di jawa timur dihasilkan limbah padat / afalan proses kemasan berupa aluminium foil sekitar 8 ton tiap bulan. Selama ini proses penanganannya adalah diserahkan pihak ketiga dengan membayar sejumlah biaya. Sedangkan di lain pihak, industri yang bersangkutan juga mengoperasikan Instalasi Pengolah Air Limbah (IPAL) yang dalam salah satu prosesnya membutuhkan bahan penolong berupa tawas.

Dengan memanfaatkan limbah padat berupa afalan aluminium foil untuk membuat bahan penolong pengolahan limbah yaitu tawas yang membantu proses koagulasi, maka akan berdampak baik bagi lingkungan dengan mendapatkan beberapa manfaat sekaligus, yaitu mengurangi jumlah limbah padat yang dihasilkan dan mengurangi penggunaan dan pembelian tawas komersil untuk pengolahan IPAL sehingga biaya pengelolaan limbah baik padat maupun cair dapat berkurang.

Pendekatan Life Cycle Analysis (LCA) untuk produksi Aluminium bisa digunakan untuk mengetahui konsumsi energi untuk proses produksi aluminium ( $\mathrm{Al})$. Dengan menggunakan perbandingan Life Cycle Analysis (LCA) untuk produk primer dan sekunder produksi aluminium $(\mathrm{Al})$ diperoleh bahwa untuk konsumsi air 93,5\% digunakan dalam siklus primer, sedangan $6,5 \%$ untuk siklus sekunder. Untuk konsumsi listrik 99,3\% digunakan oleh siklus primer. Jika menggunakan aluminium (Al) yang didaur ulang (bahan baku 
sekunder) dapat mengurangi jumlah bahan baku primer, energi yang digunakan, serta dampak lingkungan yang dihasilkan. Dari besarnya energi yang diperlukan untuk menghasilkan Aluminium, maka limbah padat atau rejek dari aluminium bekas lebih baik direcycle menjadi produk aluminium kembali maupun turunannya. [4]

Sudah dilakukan beberapa penelitian untuk pemanfaatan limbah aluminium foil, antara lain pemanfaatan limbah aluminium foil menjadi gas hydrogen untuk fuel cell dengan menggunakan katalis $\left(\mathrm{H}_{2} \mathrm{SO} 4, \mathrm{NaOH}, \mathrm{KOH}\right.$ dan $\left.\mathrm{NaCl}\right)$ [5]. Membuat tawas dari logam Al yaitu kaleng bekas yang dilarutkan kedalam $\mathrm{KOH}$ dan direaksikan dengan asam sulfat akan menghasilkan endapan. Pada penelitian yang dilakukan Manurung ini menggunakan alumunium foil yang masih baru (bukan limbah) serta dalam taraf skala laboratium sebagai penelitian dasar dan tawas yang dihasilkan mampu menjernihkan air. [6]

Kapur, tawas, dan kaporit disebut koagulan karena bisa menimbulkan koagulasi. Koagulasi adalah proses penggumpalan melalui reaksi kimia, tawas ini akan mengendap dalam air bersama dengan bahan kimia pencemar air. Pengendapan terjadi bila zat-zat itu tercampur dengan baik dalam air. [7]

Beda penelitian yang dilakukan kali ini dengan penelitian yang sudah ada sebelumnya adalah, memanfaatkan limbah padat/ afalan berupa aluminium foil dengan tipe tertentu khusus untuk packaging dari industri makanan dan minuman (yang memungkinkan masih adanya printing dll ) untuk diproses menjadi tawas yang bisa dimanfaatkan sendiri oleh industri tersebut untuk bahan pembantu dalam pengolahan air limbah.

Aluminium sulfat padat dengan nama lain: alum, alum padat, aluminium alum, cake alum, atau aluminium salt adalah produk buatan berbentuk bubuk, butiran, atau bongkahan, dengan rumus kimia $\mathrm{Al}_{2}\left(\mathrm{SO}_{4}\right)_{3} \cdot \mathrm{xH}_{2} \mathrm{O}$. Kekeruhan dalam air dapat dihilangkan melalui penambahan sejenis bahan kimia yang disebut koagulan. Pada umumnya bahan seperti Aluminium sulfat $\left[\mathrm{Al}_{2}\left(\mathrm{SO}_{4}\right)_{3} \cdot 18 \mathrm{H}_{2} \mathrm{O}\right]$ atau sering disebut alum atau tawas, fero sulfat, Poly Aluminium Chlorida (PAC) dan poli elektrolit organik dapat digunakan sebagai koagulan. [11]

Tawas kalium aluminium sulfat dihasilkan dengan mereaksikan logam aluminium ( $\mathrm{Al})$ dalam larutan basa kuat (kalium hidroksida) akan larut membentuk aluminat. Larutan aluminat dinetralkan dengan asam sulfat mula-mula terbentuk endapan berwarna putih dari aluminium hidroksida $\left[\mathrm{Al}(\mathrm{OH})_{3}\right]$, yang dengan penambahan asam sulfat endapan putih semakin banyak dan jika asam sulfat berlebihan endapan akan larut membentuk kation $\mathrm{K}^{+}, \mathrm{Al}^{3+}$, dan $\mathrm{SO}_{4}{ }^{2-}$, yang jika didiamkan akan terbentuk kristal seperti kaca dari tawas kalium aluminium sulfat atau sering disebut alum. Secara singkat reaksi yang terjadi dapat dituliskan sebagai berikut :

$2 \mathrm{Al}_{(\mathrm{s})}+2 \mathrm{KOH}_{(\mathrm{aq})}+10 \mathrm{H}_{2} \mathrm{O}_{(\mathrm{l})}+4 \mathrm{H}_{2} \mathrm{SO}_{4(\mathrm{aq})} \rightarrow$

$2 \mathrm{KAl}\left(\mathrm{SO}_{4}\right)_{2} \cdot 12 \mathrm{H}_{2} \mathrm{O}_{(\mathrm{s})}+3 \mathrm{H}_{2(\mathrm{~g})}$
Larutan dipanaskan pada suhu $60-80^{\circ} \mathrm{C}$ untuk menguapkan airnya dan suhu pemanasan tidak boleh lebih dari $80^{\circ} \mathrm{C}$ karena tawas akan larut dalam air mendidih. Pada proses penguapan selama 10 menit dan didinginkan akan terbentuk kristal dari $\mathrm{KAl}\left(\mathrm{SO}_{4}\right)_{2} \cdot 12 \mathrm{H}_{2} \mathrm{O}$. Untuk setiap kali pembuatan tawas, sebagian pelarut mungkin perlu dikurangi dengan cara penguapan untuk menghasilkan larutan jenuh yang kemudian menghasilkan kristal tawas pada waktu didinginkan. Untuk pendapatkan kristal yang berukuran besar, pendinginan larutan jenuh harus dilakukan secara pelan-pelan.

Tawas yang berkualitas baik memiliki ciri-ciri berbentuk bongkahan dan tidak berwarna (bening). Pada alumunium foil juga menghasilkan sejumlah tawas, tawas tersebut berbentuk serbuk halus berwarna putih.

Penggunaan tawas sebagai penolong proses pengolahan limbah dengan cara tawas dimasukkan ke dalam air kotor/limbah dan diaduk, ion ion dan molekul air yang terikat dalam kristal tersebut tersebar lepas berada diantara molekulmolekul air yang bertindak sebagai pelarut. Persamaan reaksinya sebagai berikut.

$\mathrm{KAl}\left(\mathrm{SO}_{4}\right)_{2} \cdot 12 \mathrm{H}_{2} \mathrm{O}_{(\mathrm{s})}+\mathrm{air} \rightarrow \mathrm{K}^{+}{ }_{(\mathrm{aq})}+\mathrm{Al}_{3}{ }^{+}{ }_{(\mathrm{qq})}+2 \mathrm{SO}_{4}{ }^{2}{ }_{(\mathrm{aq})}$ $+12 \mathrm{H}_{2} \mathrm{O}_{(1)}$

Ion-ion aluminium dalam air mengalami hidrolisis, membentuk koloid $\mathrm{Al}(\mathrm{OH}) 3$. Persamaan reaksinya sebagai berikut.

$$
\mathrm{Al}^{3+}(\mathrm{aq})+3 \mathrm{H}_{2} \mathrm{O}_{(\mathrm{l})} \leftrightarrow \mathrm{Al}(\mathrm{OH})_{3(\mathrm{~s})}+3 \mathrm{H}^{+}{ }_{(\mathrm{aq})}
$$

Partikel-partikel yang tadinya membentuk gerombolan dengan diameter tertentu, akan menyatu, baik dari koloid aluminium maupun koloid air kotor/limbah. Karena awalnya terjadi tarik menarik antar kedua muatan yang berbeda, maka partikel-partikel dari kedua koloid itu bercampur dan menggumpal bersama sebagai lumpur. Istilah kimianya terjadi koagulasi. [9]

\section{BAHAN DAN METODE}

\section{A. Bahan dan Peralatan}

Bahan yang dipakai dalam penelitian ini antara lain : Limbah Padat Alumunium Foil , Larutan $\mathrm{NaOH}$ dan $\mathrm{KOH}$, Larutan $\mathrm{H}_{2} \mathrm{SO}_{4}$, Kertas Saring.

Peralatan yang dipakai dalam penelitian ini : Pemanas, Beker Glas, Corong pemisah, Pengaduk

\section{B. Metode Kerja}

- Analisa dan identifikasi limbah padat alumunium foil, jenis serta karakteristik, sifatnya printing ataupun tidak (Coated dan uncoated) 
- Proses pembuatan tawas dari alumunium foil:

- Pencacahan / pengecilan ukuran. Pengecilan ukuran aluminium foil (untuk memperbesar luas permukaan agar reaksi dapat berjalan dengan lebih cepat)

- Pelarutan dengan basa kuat (variabel yang digunakan adalah larutan basa $\mathrm{NaOH}$ dan $\mathrm{KOH}$ disertai pemanasan.

- Penyaringan untuk mendapatkan filtrat.

- Penetralan dengan larutan Asam Sulfat

- Uji karakteristik Produk Alumunium Sulfat /tawas yang dihasilkan berdasarkan SNI 0032 - 2011 mengenai Aluminium Sulfat

- Menentukan kondisi optimum dengan melihat jumlah pelarut kimia yang dipakai seminimal mungkin, tetapi dihasilkan kandungan tawas yang paling besar.

- Melakukan analisa ekonomi

\section{HASIL DAN PEMBAHASAN}

Kemasan aluminium foil memiliki banyak variasi, ketebalan dan jenis kemasan yang berbeda - beda. Oleh karena itu diambil 2 variasi besar yaitu kemasan aluminium foil yang polos (uncoated) seperti kemasan susu bubuk dan aluminium foil yang berwarna (coated) seperti kemasan snack, kopi dan sejenisnya. Karakterisasi bahan baku dilakukan untuk mengetahui kadar aluminium dan kadar abu dalam sisa afalan dari industri makanan/ minuman yang digunakan.

TABEL I. HASIL IDENTIFIKASI BAHAN ALUMINIUM FOIL

\begin{tabular}{l|c|c|c}
\hline Parameter & Satuan & $\begin{array}{c}\text { Al. Foil } \\
\text { Polos }\end{array}$ & $\begin{array}{c}\text { Al. Foil } \\
\text { Warna }\end{array}$ \\
\hline $\mathrm{Kadar} \mathrm{Abu}$ & $\%$ & 14,38 & 2,4 \\
\hline $\mathrm{Kadar} \mathrm{Al}$ & $\mathrm{mg} / \mathrm{kg}$ & 68400 & 612,25 \\
\hline $\mathrm{Fe}_{2} \mathrm{O}_{3}$ & $\mathrm{mg} / \mathrm{kg}$ & 914,286 & 22,857 \\
\hline $\mathrm{ZnO}$ & $\mathrm{mg} / \mathrm{kg}$ & 16,885 & 4,1528 \\
\hline $\mathrm{SnO}$ & $\mathrm{mg} / \mathrm{kg}$ & 42,8924 & 0,56 \\
\hline
\end{tabular}

Dari tabel 1 diatas diketahui bahwa kadar aluminium pada kemasan aluminium foil polos memiliki kadar yang lebih tinggi daripada kemasan aluminium foil yang berwarna.

Selanjutnya dilakukan tahapan penelitian awal terhadap alumunium foil, dengan melakukan reaksi 20 gr alumunium

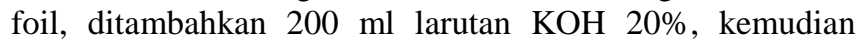
hasilnya disaring dan selanjutnya ditambahkan $150 \mathrm{ml}$ larutan $\mathrm{H}_{2} \mathrm{SO}_{4}$. 6M. Aluminium sulfat yang dihasilkan dilakukan analisa dan dibandingkan dengan Standard Nasional Indonesia (SNI 0032 - 2011 : Alumunium Sulfat) untuk Kategori alumunium Sulfat Cair.

TABEL II. HASIL ANALISA PRODUK ALUMINIUM SULFAT CAIR

\begin{tabular}{l|c|c|c|c}
\hline Parameter & Satuan & $\begin{array}{c}\text { Baku } \\
\text { Mutu*) }\end{array}$ & $\begin{array}{c}\text { Al. Foil } \\
\text { Polos }\end{array}$ & $\begin{array}{c}\text { Al. Foil } \\
\text { Warna }\end{array}$ \\
\hline $\mathrm{Al}_{2} \mathrm{O}_{3}$ & $\%$ & Min 8 & 0,73 & 0,48 \\
\hline
\end{tabular}

\begin{tabular}{l|c|c|c|c}
\hline Parameter & Satuan & $\begin{array}{c}\text { Baku } \\
\text { Mutu*) }\end{array}$ & $\begin{array}{c}\text { Al. Foil } \\
\text { Polos }\end{array}$ & $\begin{array}{c}\text { Al. Foil } \\
\text { Warna }\end{array}$ \\
\hline $\begin{array}{l}\text { Bagian } \\
\text { tdk larut } \\
\text { dlm air }\end{array}$ & $\%$ & Maks.0,1 & 0,04 & 0,09 \\
\hline $\mathrm{Fe}$ & $\%$ & Maks.0,1 & 0,0013 & 0,0017 \\
\hline $\mathrm{Pb}$ & $\mathrm{mg} / \mathrm{kg}$ & Maks. 50 & $<2$ & $<2$ \\
\hline $\mathrm{As}$ & $\mathrm{mg} / \mathrm{kg}$ & Maks. 50 & 0,79 & 0,47 \\
\hline $\begin{array}{l}\mathrm{H} \mathrm{SO} \\
2 \\
\text { bebas }\end{array}$ & $\%$ & Maks.0,1 & 20,48 & 20,95 \\
\hline pH & - & Min 3 & 3,15 & 3,13 \\
\hline $\begin{array}{l}\text { Bobot } \\
\text { Jenis }\end{array}$ & - & Min. 1,3 & 1,23 & 1,25 \\
\hline
\end{tabular}

*) SNI $0032-2011$

TABEL 3. HASIL ANALISA PRODUK ALUMINIUM SULFAT PADAT

\begin{tabular}{l|c|l|l|l}
\hline Parameter & Satuan & $\begin{array}{l}\text { Baku } \\
\text { Mutu *) }\end{array}$ & $\begin{array}{l}\text { Al. Foil } \\
\text { Polos }\end{array}$ & $\begin{array}{l}\text { Al. Foil } \\
\text { Warna }\end{array}$ \\
\hline $\begin{array}{l}\mathrm{Al} \mathrm{O}_{2} \\
\begin{array}{l}\text { Bagian tdk } \\
\text { larut dlm } \\
\text { air }\end{array}\end{array}$ & $\%$ & Min. 17 & 11,85 & 4,89 \\
\hline $\mathrm{Fe}$ & $\%$ & $\begin{array}{l}\text { Maks. } \\
0,5\end{array}$ & 1,69 & 28,37 \\
\hline $\mathrm{Pb}$ & $\mathrm{mg} / \mathrm{kg}$ & Maks. 50 & $<2$ & $<2$ \\
\hline $\mathrm{As}$ & $\mathrm{mg} / \mathrm{kg}$ & Maks. 50 & 5,04 & 22,82 \\
\hline $\begin{array}{l}\mathrm{H} \mathrm{SO} \\
2 \\
\text { bebas }\end{array}$ & $\%$ & $\begin{array}{l}\text { Maks. } \\
0,1\end{array}$ & $<0,1$ & $<0,1$ \\
\hline
\end{tabular}

*) SNI $0032-2011$

Dari tabel. 2 dan 3 diatas terlihat kandungan $\mathrm{Al}_{2} \mathrm{O}_{3}$ yang dihasilkan baik dalam bentuk padat maupun cair belum memenuhi syarat mutu berdasarkan SNI, hal ini karena bahan baku yang digunakan hanya memiliki kadar aluminium sekitar $0,1-7 \%$. Namun hal ini tidak menjadi masalah karena target akhir bukan untuk dikomersilkan/diperjualbelikan hanya untuk pemakaian internal dalam industri sendiri. Pemakaian aluminium sulfat dalam IPAL sendiri dalam bentuk cair yang sudah disesuaikan dengan kandungan yang digunakan/dibutuhkan dalam IPAL industri tersebut, maka untuk menghemat proses dan biaya, aluminium sulfat yang akan dibuat adalah dalam bentuk cair, tidak perlu dijadikan ke padat. Secara umum beberapa persyaratan mutu seperti kandungan logam sudah memenuhi persyaratan mutu aluminium sulfat, artinya tidak ada zat inert yang dapat mengganggu proses pengolahan limbah ataupun menambah beban IPAL jika aluminium sulfat ini digunakan sebagai koagulan, hanya nilai kandungan $\mathrm{Al}_{2} \mathrm{O}_{3}$ sangat kecil, sehingga dalam aplikasinya membutuhkan jumlah yang lebih banyak dibandingkan aluminium sulfat komersil. Pada aluminium sulfat cair kandungan $\mathrm{H}_{2} \mathrm{SO}_{4}$ bebas terlihat masih tinggi, hal itu disebabkan dari sisa pereaksi yang merupakan larutan $\mathrm{H}_{2} \mathrm{SO}_{4}$ pekat $6 \mathrm{M}$ yang tidak ikut bereaksi, oleh karena itu perlu dicari proses optimal pemakaian jumlah asam sulfat untuk mengurangi biaya dan hasil tawas cair yang dihasilkan memenuhi persyaratan SNI serta tidak mengganggu kinerja IPAL. 
Untuk mendapatkan kondisi optimum proses maka dilakukan beberapa variasi percobaan. Variasi yang digunakan antara lain variasi basa yang digunakan yaitu $\mathrm{KOH}$ dan $\mathrm{NaOH}$, variasi konsentrasi asam dan basa yang digunakan, sehingga diharapkan mendapatkan hasil asam sulfat yang besar dengan pemakaian bahan kimia yang sedikit.

Selanjutnya dilakukan beberapa variasi percobaan untuk menentukan kondisi optimumnya. Dibuat variabel : konsentrasi $\mathrm{NaOH} / \mathrm{KOH}(2.5 \%, 5 \%, 7.5 \%$ dan $10 \%)$ serta konsentrasi larutan $\mathrm{H}_{2} \mathrm{SO}_{4}$. $(0.75 \mathrm{M}, 0.9 \mathrm{M}, 1 \mathrm{M}$ dan $1.25 \mathrm{M})$

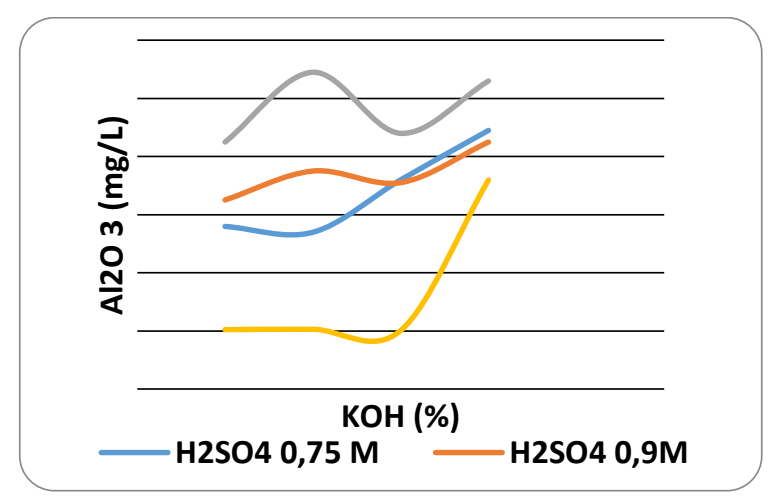

Gambar 1. Hubungan $\% \mathrm{KOH}$ Terhadap $\% \quad \mathrm{Al}_{2} \mathrm{O}_{3}$ Pada Beberapa Konsentrasi $\mathrm{H}_{2} \mathrm{SO}_{4}$

Pada kurva gambar. 1 dapat dilihat titik puncak terletak pada pemakaian $\mathrm{H}_{2} \mathrm{SO}_{4} 1 \mathrm{M}$ dengan kadar $\mathrm{KOH} 5 \%$, hal ini menunjukkan pada titik ini adalah kondisi optimum dimana diperoleh kadar $\mathrm{Al}_{2} \mathrm{O}_{3}$ sebesar $0,88 \%$.

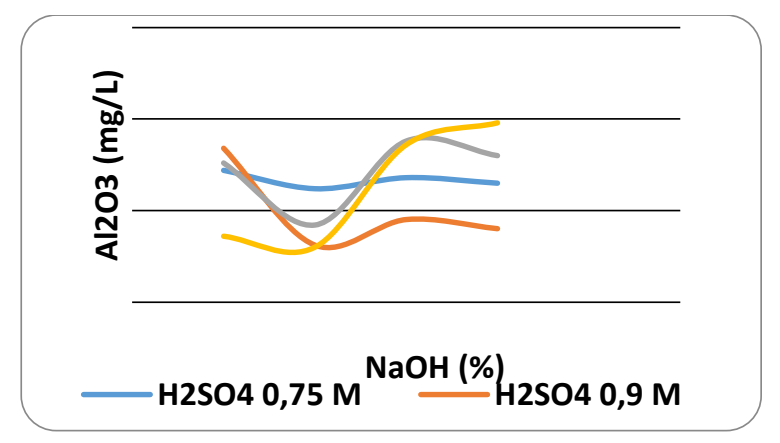

Gambar 2. Hubungan \% NaOH Terhadap $\% \quad \mathrm{Al}_{2} \mathrm{O}_{3}$ Pada Beberapa Konsentrasi $\mathrm{H}_{2} \mathrm{SO}_{4}$

Pada kurva gambar 1 dapat dilihat titik puncak terletak pada pemakaian $\mathrm{H}_{2} \mathrm{SO}_{4} 1 \mathrm{M}$ dengan kadar $\mathrm{NaOH} 7,5 \%$, hal ini menunjukkan pada titik ini adalah kondisi optimum dimana diperoleh kadar $\mathrm{Al}_{2} \mathrm{O}_{3}$ sebesar $0,89 \%$. Hal ini bisa diartikan bahwa pada kondisi optimum ini semua kadar $\mathrm{Al}$ telah bereaksi sempurna menjadi $\mathrm{Al}_{2} \mathrm{O}_{3}$.

Dengan mendapatkan kondisi optimum proses maka dilakukan variasi bahan baku, yaitu aluminium foil yang polos (uncoated) dan aluminium foil yang berwarna (coated) yang direaksikan pada kondisi optimum menggunakan $\mathrm{H}_{2} \mathrm{SO}_{4} 1 \mathrm{M}$ dengan kadar $\mathrm{KOH} 5 \%$ dan $\mathrm{NaOH}$ dengan kadar $7,5 \%$

TABEL IV. KONDISI OPTIMUM HUBUNGAN \% KOH MAUPUN \% NAOH TERHADAP $\% \quad \mathrm{Al}_{2} \mathrm{O}_{3}$

\begin{tabular}{|c|c|c|c|}
\hline Type Al Foil & & $\mathrm{KOH}$ & $\mathrm{NaOH}$ \\
\hline \multirow{4}{*}{$\begin{array}{r}\text { Polos / Un } \\
\text { Coated }\end{array}$} & Konsentrasi & $5 \%$ & $7.5 \%$ \\
\hline & $\mathrm{H}_{2} \mathrm{SO}_{4}$ & $1 \mathrm{M}$ & $1 \mathrm{M}$ \\
\hline & $\mathrm{Al}_{2} \mathrm{O}_{3}$ & $3.1 \%$ & $0.89 \%$ \\
\hline & Waktu & \multicolumn{2}{|c|}{15 menit } \\
\hline \multirow{4}{*}{$\begin{array}{r}\text { Berwarna / } \\
\text { Coated }\end{array}$} & Konsentrasi & $5 \%$ & $7.5 \%$ \\
\hline & $\mathrm{H}_{2} \mathrm{SO}_{4}$ & $1 \mathrm{M}$ & $1 \mathrm{M}$ \\
\hline & $\mathrm{Al}_{2} \mathrm{O}_{3}$ & $2.1 \%$ & $0.88 \%$ \\
\hline & Waktu & \multicolumn{2}{|c|}{15 menit } \\
\hline
\end{tabular}

Pada tabel 4 diatas diperoleh bahwa dengan proses yang sama kadar $\mathrm{Al}_{2} \mathrm{O}_{3}$ yang dihasilkan dari limbah aluminium foil polos (uncoated) lebih besar daripada limbah aluminium foil yang berwarna (coated) karena kandungan $\mathrm{Al}$ pada kemasan aluminium foil polos lebih tinggi. Dari tabel diatas juga dapat dilihat bahwa reaksi dengan $\mathrm{KOH}$ mampu menghasilkan aluminium sulfat yang jauh lebih besar daripada menggunakan $\mathrm{NaOH}$.

Hasil reaksi $\mathrm{Al}$ dengan $\mathrm{NaOH}$ menghasilkan aluminat yang jika dinetralkan dengan asam akan membentuk kristal $2 \mathrm{NaAl}\left(\mathrm{SO}_{4}\right)_{2} .12 \mathrm{H}_{2} \mathrm{O}$, Sodium aluminium sulfate atau soda alum. Soda alum ini digunakan sebagai zat aditif pada makanan, bahan utama pembuatan baking powder. [10] Sehingga meskipun $\mathrm{KOH}$ dan $\mathrm{NaOH}$ sama - sama basa kuat yang mampu bereaksi dengan Aluminium, namun memiliki fungsi yang berbeda. Untuk menjadikan limbah padat afalan aluminium foil menjadi koagulan lebih tepat mereaksikannya dengan basa $\mathrm{KOH}$. Oleh karena itu untuk uji performa aluminium sulfat adalah aluminium sulfat yang dihasilkan dari proses reaksi dengan $\mathrm{KOH}$.

Untuk memastikan aluminium sulfat yang dihasilkan bisa digunakan sebagai koagulan maka dilakukan uji performance aluminium sulfat yang dihasilkan terhadap air limbah dan dibandingkan dengan performance tawas komersil pada kondisi proses IPAL yang sama. TSS di uji menggunakan metode gravimetri sesuai dengan SNI 066989.3-2004 sedangan kekeruhan dihitungmenggunakan turbidimeter.

TABEL V. HASIL ANALISA PRODUK ALUMINIUM SULFAT CAIR

\begin{tabular}{l|c|c|c|c}
\hline Parameter & $\begin{array}{c}\text { Air } \\
\text { Limbah } \\
\text { Awal }\end{array}$ & $\begin{array}{c}\text { Air } \\
\text { Limbah+ } \\
\text { tawas } \\
\text { komersil }\end{array}$ & $\begin{array}{c}\text { Air Limbah } \\
+ \text { tawas } \\
\text { dari afalan } \\
\text { polos }\end{array}$ & $\begin{array}{c}\text { Air Limbah+ } \\
\text { tawas dari } \\
\text { afalan } \\
\text { berwarna }\end{array}$ \\
\hline $\mathrm{pH}$ & 2.76 & 3.69 & 3.82 & 2.1 \\
\hline $\mathrm{TSS}$ & 340 & 15 & $<1$ & $<1$ \\
\hline Kekeruhan & 20.4 & 6.4 & 5.8 & 4.28 \\
\hline
\end{tabular}

Dari hasil uji performance pada tabel 5 bisa dilihat bahwa dengan konsentrasi aluminium sulfat yang sama, $\mathrm{Al}_{2} \mathrm{O}_{3}$ yang 
dihasilkan dari penelitian ini baik menggunakan aluminium (Al) polos maupun berwarna mampu menurunkan TSS dan kekeruhan sebaik tawas komersil, hanya jumlah yang digunakan untuk mendapatkan konsentrasi yang sama perlu jumlah yang lebih banyak karena kadar $\mathrm{Al}_{2} \mathrm{O}_{3}$ yang dihasilkan masih sangat kecil. Kadar pH limbah awal sangat asam sekitar 3, penambahan aluminium sulfat tidak terlalu berpengaruh ke perubahan $\mathrm{pH}$, justru menaikkan sedikit nilai $\mathrm{pH}$ sehingga menjadi tidak terlalu asam.

\section{Evaluasi Teknologi}

Beberapa hal yang dapat diambil dan dimanfaatkan dari hasil penelitian ini antara lain :

- Teknologi ini dapat diimplementasikan pada beberapa industri yang mempunyai kondisi serupa seperti pada industri yang mempunyai kemasan berupa alumunium foil, karena limbah padat alumunium foil mempunyai potensi untuk dimanfaatkan . Pemanfaatannya untuk dimanfaatkan untuk membuat alumunium sulfat yang pada akhirnya dapat dimanfaatkan sebagai bahan penolong pengolahan limbah di industri yang bersangkutan .

- Disini terjadi suatu peluang untuk memanfaatkan kembali limbah padat / afalan alumunium foil yang dihasilkan untuk bisa dimanfaatkan.

- Hasil samping dari proses ini masih menghasilkan limbah padat berupa plastik, oleh karena itu perlu dilakukan kajian lebih lanjut untuk memanfaatkan plastik sisa reaksi.

\section{Evaluasi Ekonomi}

Dari kondisi optimum yang didapat kandungan aluminium sulfat yang dihasilkan sebesar 3,1\% hal ini masih sangat jauh dengan kandungan kristal tawas komersil yang kandungan aluminium sulfatnya lebih dari $17 \%$ dan kandungan aluminium sulfat pada PAC yang lebih dari $5 \%$. Serta harga dari kristal tawas cukup murah. Sehingga evaluasi ekonomi untuk suatu kegiatan pengelolaan lingkungan yang diakibatkan oleh kegiatan usaha, tidaklah mudah untuk di hitung untung ruginya, hal itu dikarenakan biaya yang ada seharusnya dibandingkan dengan terjadinya kerusakan lingkungan serta usaha pemulihannya apabila tidak ada pengelolaan.
Dengan salah satu pertimbangan tersebut serta sebagai perwujudan rasa tanggung jawab pengelolaan yang baik dari dampak kegiatan industri/ unit usaha, maka sekecil apapun limbah yang dihasilkan haruslah mendapatkan perhatian untuk mengolahnya.

\section{KESIMPULAN}

Limbah afalan aluminium foil dapat dimanfaatkan menjadi salah satu koagulan pada proses IPAL yaitu berupa tawas / aluminium sulfat, dan memiliki kemampuan sama baiknya dengan tawas komersil, namun tawas yang dihasilkan kadarnya masih sebesar $3,1 \%$ dan masih menghasilkan limbah padat berupa plastik bening sehingga harus dilakukan penelitian lebih lanjut untuk mengurangi jumlah limbah padat yang ada.

\section{UCAPAN TERIMA KASIH}

Ucapkan terima kasih ditujukan kepada Balai Riset dan Standardisasi Surabaya untuk dukunganya, sehingga penelitian ini bisa dilaksanakan.

\section{DAFTAR PUSTAKA}

[1] Austie, George T, 1986, “Shreve”s Chemical Process Industries ", 5 th ed, Mc.Graw Hill, New York.

[2] Perry, RH \& Green D, 1985, “Perry's Chemical Engineers' Hand Book ", $6^{\text {th }}$ ed, Mc.Graw Hill, New York.

[3] Ditjen IKM. 2007. "Pelatihan Kemasan Fleksibel” Kementerian Perindustrian. Jakarta.

[4] Olfat El-Sebaie, Manal Ahmed, Ahmed Hussin. 2006. "Life cycle Analysis of Aluminum Foil Packaging Material". The Journal of the Egyptian Public

[5] Health Association (JEPHAss.) Vol.81 No. 3\& 4. Mesir.

[6] Siregar Yusraini. 2010. "Produksi Gas Hidrogen dari Limbah Aluminium”. Jurnal Valensi Vol. 2 No.1. Jakarta

[7] Manuntun Manurung dan Irma Fitria Ayuningtyas. 2010. "Kandungan Aluminium dalam Kaleng Bekas dan Pemanfaatannya dalam Pembuatan Tawas". Jurnal Kimia 4. Bali.

[8] Ummu Kalsum. 2014. "Pembentukan Tawas dari Aluminium Foil". Jurnal Praktikum Kimia Anorganik UIN Syarif Hidayatullah. Jakarta

[9] Vogel. 2005. "Buku Teks Analisis Anorganik Kualitatif Makro dan Semimikro", edisi ke Lima. PT. Kalman Media Pustaka. Jakarta

[10] https://en.wikipedia.org/wiki/Sodium_aluminium_sulfate 